\title{
Innovation or Technological Madness? A Research on Innovation and Technology Perception of University Students
}

\author{
Cenk Aksoy ${ }^{1}$
}

\begin{abstract}
This research aims to determine the purpose of pursuing the technology, the level of internet and smartphone usage, which are important in technology, and the effects of innovation on their lives of the university students who are expected to keep up with innovative exchanges and developments. Data were collected through the technology usage scale developed by different researchers in the research. Firstly, the validity and reliability of the scale were tried to be tested on the obtained data and then the questionnaire data were evaluated through various statistical analyzes in accordance with the purpose of the study. As a result, it has been seen that the level of technology usage of university youth has changed according to the current conditions. Considering the answers of students have participated in the research, it is possible to state that their answers to the questions about technology and innovation concepts are at the medium level. It can be said that students see technology as a lifestyle rather than madness and they see technology as a part of their lives. It has been also determined that the results of the study overlap with the results of previous researches.
\end{abstract}

Key Words: Innovation, Technology, Technology Usage, University Students

\section{Introduction}

Today, it is possible to say that technology is the most influential factor in human life. The use of technology, which has become an indispensable part of business life and social life, is increasing day by day. Technology or, more clearly, communication actors actively act in the business world. The mobile phone, which is used only for communication during the first period, has become an effective tool today in the context of business development, mobile tracking system, storage and logistics of the business world.

There are different types of research on different age groups and samples in the literature on technology, technology use and levels (Zincirkıran and Tiftik, 2014, Seyitoğulları and Yalçınsoy, 2016). Although the results of the researches differ, it is seen that trends in technology use of young people in general terms are shaped according to today's conditions. Research has revealed that young people cannot think of a life without technology and are engaged in technological tools with no boundaries. Advances in information and communication technologies have led to the widespread and frequent use of technological devices such as smartphones, computers and tablets

\footnotetext{
${ }^{1}$ Ph.D. Research Assistant, Dicle University, School of Civil Aviation, Department of Aviation Management, Diyarbakır/Türkiye.
} 


\section{HPSCONF}

8th International Conference on

Humanities, Psychology and Social Science

October 19-21, 2018 Munich, Germany

that are among the means of accessing the internet and social media among university students. For this reason, studies aiming to measure attitudes towards such technological innovations have gained importance today. In this context, what is the technological point of view of university students and what is the level of technology usage? The question emerged as a research question.

\section{Method}

The research was implemented on 362 students in a state university of Turkey, in 2017. The scale used to determine students' understanding of following up technology and reasons behind their technology preferences. Validity and reliability analyses, factor analysis, confirmatory factor analysis, frequency analyses, descriptive statistical analysis and ANOVA analysis are used for analyzing the data.

This scale was developed by Zincirkiran and Tiftik (2014) for the purpose of determining the levels of technology usage of the university students. These sentences in a Likert typeface are prepared in a scale of: "Very often" (5) "Often" (4) "Sometimes" (3), "Seldom" (2), "Never" (1). Cronbach Alpha reliability analyses and factor analysis (Reliability Analysis) have been applied on the data obtained as a result of the test. It has been seen that the factors gather in different dimensions according to to the research of Zincirkıran and Tiftik (2014), as a result of the factor analysis applied with Principal Components Analysis. As a result of the reliability analyses, the Cronbach Alpha reliability coefficient of the scale has been calculated as 0.82 .

\section{Findings}

Unlike the initial research by Zincirkıran and Tiftik (2014), who developed the scale, the factor sequences differed. In this study, the total variance of the factors was found to be higher than the results of the first scale. The results of this study are similar to those of the first scale, although their sequence is different in terms of the number of factors. The results of the KMO test on whether the size of the sample used was sufficient were determined as 0.853 . This result shows that data can be used for factor analysis. The Bartlett test was performed to determine if there is a relationship between variables. The result is zero (0.000), so the result is considered significant. The overall average of the responses of students to the measure of technology usage was found to be 2,8167 . In the first scale, this result was detected as 2,7719 , and the results of both researchers overlap each other. This situation can be interpreted as the fact that the technological aspects of the students have not changed over the years.

As a result of ANOVA and t-Test analysis between technology usage scale and demographic variables, no significant difference was found among other demographic variables except income status. There was also no significant difference between smartphone and mobile internet usage and technology usage levels. This situation is supporting the findings of the research. This may be due to the desire of young people (regardless of age, gender, education level etc.) to consume the technology quickly. This confirms the point of the research. There was also no significant difference between smartphone and mobile internet usage and technology usage levels. This is a different finding that expresses the same end result as mentioned above. 
According to the ANOVA analysis according to the income situation, the technology usage level of those with income of $1000 \$$ and above was found higher (F: 3.20, P $<0.005)$.

\section{Conclusion and Discussion}

As a result of the research, it is concluded that the "Technology Usage" scale developed by Zincirkiran and Tiftik (2014) is valid and reliable. Unlike the research of the authors who developed the scale in the research, factor sequence has changed. This may be due to the large number of sample numbers as well as the inclusion of all the statements in the measure into the analysis.

The level of technology usage of university students overlaps with the results of previous researches (Zincirkıran and Tiftik, 2014; Seyiotoğulları and Yalçınsoy, 2016). This situation can be interpreted as the validity and reliability of the research scale, as well as the fact that the technological aspects of young people do not change periodically and have a certain point of view and culture. There are partial differences in some expressions in the scale. For example, the first studies have shown that young people differ in their use of technology according to subsequent research and may be due to young people's assessment of technology as an indispensable basic need. According to the analysis result made according to the income situation, the technology usage levels of those with the highest income were found higher. This result can be interpreted as the fact that the individuals with financial sufficiency are caused by their tendency to use the technology at the highest level. In addition, although $37.6 \%$ of the survey participants had income between $200 \$$ and $400 \$$, smartphone usage rate was $96.1 \%$ and mobile internet usage rate was $94.2 \%$. This situation can be interpreted as the fact that the demand for young people especially smart phone and internet is heard without regard to the level of income, and that the smart phone and internet have increased to the level of basic necessity.

There are studies that have similar results to the findings of this study (Kuyucu, 2017: $355)$. In addition, there are studies that reach different results according to findings of study (Yirci ve Aydoğar, 2017: 2175).

The results of the research can be evaluated by social scientists in different fields, such as economists, marketers and social psychologists, in comparison with similar studies. An effective assessment of the results of the research can be used by relevant stakeholders to avoid adverse outcomes such as consumption addiction as well as technology dependency. For the evaluations to be made it is necessary for young people to understand what purpose and how they use the technology.

\section{References}

Kuyucu, M. (2017). Gençlerde akıllı telefon kullanımı ve akıllı telefon bağımlılığı sorunsalı: "Akıllı Telefon(Kolik)" Üniversite Gençliği, Global Media Journal TR Edition, 7 (14), 328-359.

Seyitoğulları O., \& Yalçınsoy A. (2016). Günümüz Gençliğinin İnovasyon ve Teknoloji Algılarına Yönelik Ampirik Bir Araştırma. International Journal of Social Academia, 1(1), 13-23. 
Yirci, R. ve Aydoğar, N. (2017). Üniversite öğrencilerinin bilgi ve iletişim teknolojilerine yönelik tutumlarının bazı değişkenler açısından incelenmesi. Ulakbilge, 5(18), 2175-2203.

Zincirkıran, M., \& Tiftik, H. (2014). İnovasyon Mu? Teknolojik Çılgınlık Mı: İnovasyon ve Teknoloji Tercihlerine Yönelik İşletme Öğrencileri Üzerine Bir Araştırma. International Journal of Academic Research in Business and Social Sciences, 4(2), 320-336. 